\title{
IPO and CSR: An Analysis on Last Performance in Italian Stock Exchange
}

\author{
Francesco Bollazzi, Giuseppe Risalvato \\ LIUC University, Castellanza, Italy \\ Giada Zanatta \\ H-Farm, Roncade, Italy
}

\begin{abstract}
The aim of this paper is to study the importance of the CSR on the performance of newly listed company at the Italian Stock Exchange with a focus on the impact of environmental, social and government responsibility, studying the performance of the first day of listing. The authors want to test if there is an advantage in terms of lower underpricing related to the preparation of a sustainability report, a document that allows reducing the information asymmetry or if, contrarily, the factors related to ESG Corporate Responsibility are not considered, by the players of the listing process, under the offer price definition, but they are otherwise valued by the market, with the consequence of a higher underpricing for IPOs of the virtuous companies. The paper presents an empirical analysis on a sample of 84 IPOs admitted to Italian Stock Exchange between 2009 and 2015, in order to study the impact of ESG Corporate Responsibility on underpricing, analyzing the performance of the new companies listed. Through the univariate and multivariate analysis, the authors propose to show any relationship between performance and ESG corporate responsibility strategies.
\end{abstract}

Keywords: IPO, corporate social responsibility, performance

\section{Introduction}

The new philosophy that drives the strategy of companies and investors is "doing well by doing good"1 that combines economic goals with environmental and social responsibility objectives (Cavaco \& Crifo, 2014), CSR (Corporate Social Responsibility) and SRI (Socially Responsible Investment). The CSR is therefore also relevant in the capital markets, where companies raise capital and seek to mitigate risks. Although there is no hard and fast definition, the concept of CSR refers to a corporate culture that integrates sustainability, social and governance issues at every level of the organization and in the relationships with all stakeholders in a long-term vision (Hososa \& Suzuki, 2015).

Recently, the stock markets are beginning to promote sustainable investment: Sustainable Stock Exchanges Initiative is an initiative of the United Nations which aims to provide effective support to the stock

Francesco Bollazzi, professor of Corporate Finance, LIUC University, Castellanza, Italy.

Giuseppe Risalvato, Ph.D. in Management and Finance, LIUC University, Castellanza, Italy.

Giada Zanatta, Business analyst at H-Farm, Roncade, Italy.

Correspondence concerning this article should be addressed to Giuseppe Risalvato, C.so Giacomo Matteotti 22, Castellanza (VA) 21053, Italy

${ }^{1}$ S. Bonini, L. Mendonca, Doing good by doing well: Shaping a sustainable future, McKinsey, marzo 2011. 
exchanges in order to promote the dialogue and increase cooperation between investors, companies, and policymakers.

The $77.4 \%$ of the companies listed in the FTSE MIB have a CSR Manager, against $42.8 \%$ of the sample of listed in other markets, and $67.7 \%$ of listed FTSE MIB have an organizational unit devoted to CSR, against $42.8 \%$ of other listed companies. The $80.65 \%$ of the FTSE MIB companies draw up their sustainability report, which has become a common and essential element of the strategy of large enterprises. The sustainability report is still present for $71.43 \%$ of the firms listed in the other indexes and only for the $26.67 \%$ of unlisted. The Green Economy companies are more innovative and open to change and a possible listing is seen as a driver. In fact, the listing is a choice of extraordinary operations aimed at creating shareholder value through the financial benefits and associated operational (Lucy \& Onyekkwelu, 2014); however, to be considered also previously monetary and non-monetary costs associated with the IPO and the increasing management responsibilities.

\section{Literature Review}

The leading theory emerged in the literature to explain the underpricing phenomenon is asymmetric information (Baron \& Holmström, 1980) between the key players of the IPO, i.e. issuer, investors, investment bank, and underwriter (Brennan \& Franks, 1997). Rock (1986) theorized the existence of investors better informed than others on the perspectives and the quality of the issuing company. Less informed investors are faced with a problem of adverse selection. The implication, when the bid price is lower than the expected value of the shares, is that the less informed investors will be split in favor of those informed, while in the case that the IPO price is higher than the expected value, all shares will be bought by investors less informed. This results in an average negative return for the investors less informed, they will lose interest in the purchase of future emissions securities; to avoid this, the issuer offers a discount (hence, precisely, the underpricing) that compensates investors about information asymmetries and also encourages traders less informed to underwrite the first-issue securities, guaranteeing them a return. Benveniste and Spindt (1989) showed that during the bookbuilding, underwriters push informed investors to reveal their decisions about the amount and price for which they will buy. The defensive behavior of informed investors not to disclose positive information of pre-sales is explained by the interest in a lower offer price. In this case the underwriter sets a lower price to ensure a profit from underpricing to reward investors revelations. Beatty and Ritter (1986) were the first in the literature to deal with asymmetric information between investors and issuers, confirming the existence of a direct relationship between underpricing and the degree of uncertainty of company value. Higher the grade of uncertainty about the expected value of the enterprise, higher will be the number of investors who will invest in information before subscribing the offer, highlighting the adverse selection problem: the greater risk carried by uninformed investors must be compensated by a higher expected return, through fixing a lower bid price. Allen and Faulhaber (1988) and Ritter and Welch (2002) pointed that only companies know the quality of their investment projects; for this reason, underpricing is a credible signal to investors about the company's quality. Only companies "good", in fact, can support this "cost”, because, if they are able to demonstrate to the market their quality and to have a positive evaluation by investors, they will be able to recover it in the following placements that will happen at more favorable prices. The studies on theories of asymmetric information appear to be credited, in fact, many researchers (Ruud 1993; Moore, 2014) have demonstrated the positive impact of some tools that issuers can use to disseminate information and reduce uncertainty on underpricing: a high 
quality information prospectus, the coverage of analysts, the choice of intermediaries that complete the placement on the market, age and size of the issuer, the presence of funds and VCs, by nature informed investors, the policy of management regarding future revenues of the companies and other financial information are all correlated with a lower underpricing.

\section{The Methodology and Model}

The empirical analysis considers the 94 companies listed between 1/1/2009 and 31/12/2015 at Borsa Italiana $^{2}$. From the initial sample the authors excluded bankrupt companies, SPAC, in liquidation, incorporated or merged into another company or delisted. The final dataset consists of 84 companies. Among these, nine companies are included in the STAR segment, 13 are included in the MTA Italy, and 62 in AIM-MAC. Among the 13 companies in the sample listed in the other lists MTA, only four publish a sustainability report: Poste Italiane, Moncler, Salvatore Ferragamo, and Yoox Net-a-Porter. There is a significant presence of companies that operate in the fields of renewable energies, 12 out of 62, in addition to those that operate in organic food, agriculture, and eco-sustainable technologies. The profile that emerges is that of a reality of Italian SMEs sensitive to environmental, social and governance responsibility and in many cases with business models based on ESG Corporate Responsibility.

Table 1

Sample of Analysis

\begin{tabular}{lll}
\hline Market & No. of IPO & No. of company with the sustainability report \\
\hline MTA & 13 & 4 \\
STAR & 9 & 1 \\
AIM Italia-Mac & 62 & 2 \\
Tot. & 84 & 7 \\
\hline
\end{tabular}

To analyze the performance of socially responsible companies this paper considers a number of variables that can identify different aspects of businesses.

Dependent variables: Underpricing ${ }^{3}, \mathrm{ROE}^{4}$.

Independent variables: Green $\mathrm{SHOE}^{5}$, Sustainability Report ${ }^{6}$, Investment Funds (VC) ${ }^{7}$, Variables ESG CR.

Also the authors added some independent variables related to environmental, social and governance corporate responsibility.

Environmental responsibility: A green company is characterized by a strong component of innovation in products and processes. A dummy variable was constructed assuming value one if the company has a green core business as: i) it produces and/or provides renewable energy; ii) it uses green chemistry to convert old, polluting technologies in clean processes and products; iii) it produces or markets organic products (in the

\footnotetext{
${ }^{2}$ www.borsaitaliana.it.

${ }^{3}$ Calculated as the difference in percentage between the placing price of the stock and the price at the end of the first day of quotations.

${ }^{4}$ Of the year before the listing calculated as the ratio between net income and equity.

${ }^{5}$ Exercising green shoe option, dummy variable equals to 1 when option has been exercised at least in part by banks responsible to accomplish placement, value 0 when it has not been exercised.

${ }^{6}$ Dummy variable is equal to 1 if the listed company publishes sustainability report and 0 otherwise.

${ }^{7}$ VC (IPO VENTURE BACKED), dummy variable equals to 1 if there are investment funds, 0 otherwise.
} 
agricultural field or food) or eco-friendly; iv) it provides services for environmental protection (e.g. waste management). In addition, firms that do not have a green core business but are committed to: i) using efficiently raw materials, energy, and water; ii) using energy from renewable sources; iii) reducing emissions and waste; iv) using materials or products, also subsidiary, eco-friendly as recyclable or environmentally friendly products; v) creating products that integrate eco-sustainability characteristics. In contrast, value 0 is assigned to companies that do not engage in any of the areas listed above.

Supplier assessment in terms of CSR: It has been attributed to the dummy variable value one in the case of companies with an ethical code and with: i) defined procedures to ensure suppliers equal treatment, transparency, and objectivity; ii) precise quality standards of supplied service/product, in accordance with control system and risk management, as well as environmental and social responsibility commitments undertaken by the company. It was assigned the value 0 to the dummy variable in the case of companies not meeting these criteria.

Support to the community: It has been attributed to the dummy value one for companies that have undertaken at least one of these initiatives: i) seek and promote young talents in the industry in which the company operates; ii) the share of corporate growth with the surrounding community through partnerships with NGOs and non-profit organizations to organize events and demonstrations to finance for benefit of disadvantaged communities programs; iii) promotion of the artistic and cultural heritage of the country; iv) funding of national and international social initiatives in support of neighboring communities and/or distant to the territory in which the company operates. The companies that have not taken any of the listed activities was attributed to the dummy value 0 .

Responsible corporate governance: The current level of information transparency on a market, according to the traditional finance theory on efficient markets, influences the process of price discovery, price convergence towards efficient values, and liquidity of the market. It has been attributed a value of one to the dummy variable in the case of companies considered leaders in terms of fairness and transparency of information because they jointly have: i) code of ethics; ii) model 231, otherwise 0 .

\section{The Findings}

The purpose of the analysis is to understand whether the commitment of business in terms of ESG and CSR influences the performance of the IPOs, in particular regarding underpricing and ROE. In the first instance, the relationship between the variables will be analyzed by univariate analysis and specifically through the method of hypotheses verification on two populations: the t-test allows comparing the average of two populations that do not correspond, taking as null hypothesis $\left(\mathrm{H}_{0}\right)$, to reject or confirm, the equality of the two averages and, therefore, of the two populations.

\section{Univariate Analysis-Environmental Responsibility and Performance}

Approximately $43 \%$ of the sampled companies, 36 companies out of 84 , are considered environmentally responsible, since they have a green core business or undertake to be responsible in this area through specific programs. Among these companies, 20 are SMEs listed on $\mathrm{AIM}^{8}$ Italy therefore young companies with high growth potential that demonstrate a growing commitment to ESG Corporate Responsibility among the most companies that compose the Italian economy, the SMEs. The group of 36 green companies has an average

\footnotetext{
${ }^{8}$ www.aimnews.it.
} 
underpricing of 5.87\%, compared to $5.634 \%$ of the whole of companies not responsible from an environmental point of view and the median value of the first group amounted to $0.045 \%$, against the $1.995 \%$ of the second (Table 2). The graph below shows the relative frequency distribution of underpricing values observed in the two groups of companies: the two frequency distributions do not seem at this first analysis significantly different.

Table 2

Underpricing of Environmentally Responsible Companies Versus Those Considered Not Responsible in the Same Field

\begin{tabular}{lll}
\hline & Underpricing, environmental resp. $=1$ & Underpricing, environmental resp. $=0$ \\
\hline Number of values & 36 & 48 \\
Median & 0.045 & 1.995 \\
Mean & 5.87 & 5.634 \\
\hline Unpaired $t$-test & \\
\hline$P$ value & & \\
Significantly different $(p<0.05)$ & & 0.9434 \\
\hline
\end{tabular}

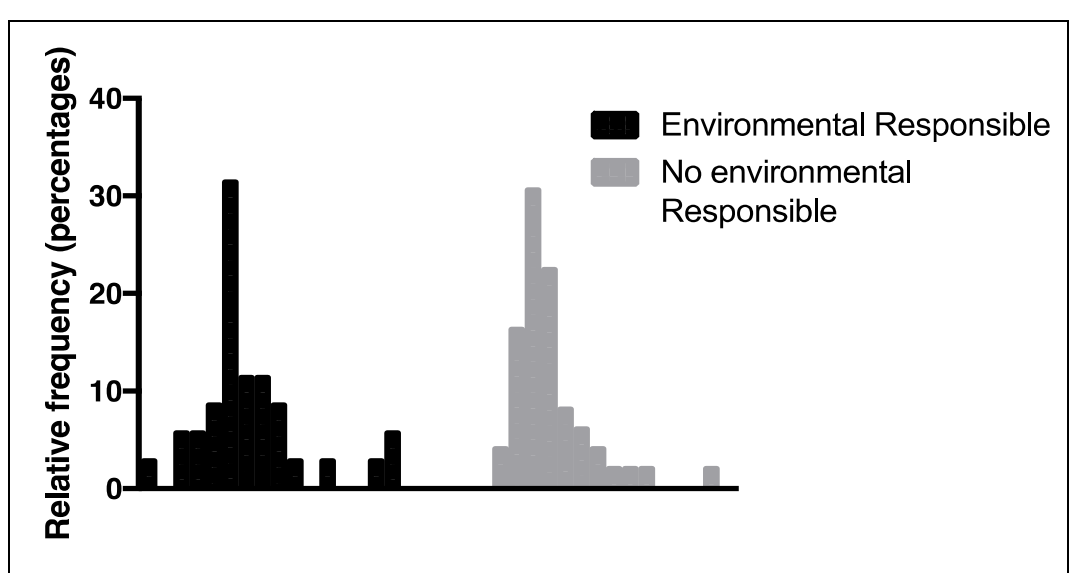

Figure 1. Frequency distribution of observed data in underpricing of environmentally responsible and not responsible companies.

$\mathrm{Hp}_{0.1}$ : The underpricing of the environmental responsible companies is not significantly different from those not responsible in this context.

The average underpricing of the two groups is not significantly different: the unpaired $t$-test on the two populations showed a $p$-value equal to 0.9434 which does not allow rejecting the null hypothesis $\mathrm{Hp}_{0.1}$. The average underpricing of the two populations is consistent with a study on the IPO of Italian Stock Exchange, which shows that between 2001 and 2012 the average underpricing was 6.75\% with a downward trend in average percentage terms due to increasing efficiency of the market and especially of bookbuilding procedures (Dell’Acqua, Etro, Leonardo, Murri \& Tetia, 2014). Considering the negative results of this preliminary analysis, the analysis proceeds by verifying whether the accounting performance of sustainable companies from the environmental point of view reflects this commitment. The same type of univariate analysis, in fact, was repeated considering the average values of ROE (Table 3) calculated on balance sheet data of the year before the listing. The emerging data show that the companies responsible from an environmental standpoint obtain excellent results in terms of return on equity, $20.85 \%$ versus $14.74 \%$ of the companies considered not 
responsible in this field. Despite this, the statistic shows how the two populations are not sufficiently different from each other and the null hypothesis $\mathrm{Hp}_{0.2}$ can not be rejected. The average values of the two populations appear very good if we consider the data of report Cerved 2015 that shows the trend of turnovers of large enterprises and Italian SMEs, a sector well represented in the sample under analysis: ROE of Italian SMEs is grew from $5.9 \%$ in 2013 to $7.1 \%$ in 2014, surpassing the one generated by large companies, which instead is decreased from $6.8 \%$ to $6.4 \%$, while remaining lower than 2008 levels.

$\mathrm{Hp}_{0.2}$ : The $\mathrm{ROE}$ of the companies responsible from an environmental perspective is not significantly different from the ROE of the companies not responsible from the same point of view.

Table 3

Analysis of ROE Values of the Environmentally Responsible Companies Versus Those Considered Not Responsible in This Context

\begin{tabular}{lll}
\hline & ROE, environmental resp. $=1$ & ROE, environmental resp. $=0$ \\
\hline Number of values & 36 & 48 \\
Median & 11.92 & 10.77 \\
Mean & 20.85 & 14.74 \\
\hline Unpaired $t$ test & & \\
\hline$P$ value & & 0.2759 \\
Significantly different $(p<0.05)$ & & No \\
\hline
\end{tabular}

Univariate Analysis-The SMEs of the AIM Italy: Environmental Sustainability and Performance

The number of SMEs at AIM Italian is constantly growing with a $+47 \%$ only in 2014 over the previous year; even in 2015 there were 22 new listings, with 278 million capital raised. In the sample analyzed 62 companies out of 84 are listed on this market, which recorded good financial performance: in 2015, 75\% of these companies reported growing revenue compared to 2014 and $25 \%$ recorded growth rates of up to $10 \%$. This paragraph is designed to check whether the data of these companies, separate from data of companies listed at MTA or STAR, lead to different results. The mean, median, and standard deviation values, calculated on underpricing of the environmentally responsible and not responsible SMEs of the AIM Italy take values close to each other, albeit socially responsible companies tend to obtain on average a lower underpricing and therefore a lower cost of listing. The statistic shows, however, that the two populations are not significantly different ( $p$-value 0.6843 ) and $\mathrm{Hp}_{0.3}$, the null hypothesis, can not be rejected.

$\mathrm{Hp}_{0.3}$ : The underpricing of companies of AIM Italy responsible from an environmental perspective is not significantly different from that of companies not responsible in this area.

The analysis of ROE recorded in the two samples of companies of AIM Italy is consistent with the report published by the Observatory OPMI of SDA Bocconi: the average ROE of all Italian SMEs with revenues between five and 50 million euro between 2007 and 2012 was 9.4\%. The SMEs of the sustainable sample from an environmental point of view appear to have an ROE significantly higher than non-sustainable in this field, $22.15 \%$, against $14.89 \%$, but the inferential statistics does not conclusively show that environmental responsibility impact in a reliable and positive way on the ROE values of the AIM Italy ( $p$-value 0.3299 ). The null hypothesis $\mathrm{Hp}_{0.4}$, in fact, can not be refused.

$\mathrm{Hp}_{0.4}$ : The ROE of the companies of AIM Italy responsible from an environmental perspective is not significantly different from that of non-responsible in this area. 
Despite the fact that the statistics once again show that the two populations are not significantly different from each other, IR Top Observatory in 2015 found good fundamentals in the companies of green economy in this list, with revenue growth of $21 \%$ and an average EBITDA to $15 \%$. The growth stage of these enterprises given by peculiar features of SMEs, it is probably the dominant character and it doesn't allow distinguishing statistically the population of the environmental responsible companies from those not responsible in this area in terms of ROE. Similarly the attractiveness for the whole market, due to the high potential of profitability and demonstrated by $+35 \%$ of raised capital in 2015 compared to 2014, it is probably the cause of the non-significant difference of the two populations in terms of underpricing.

\section{Univariate Analysis-MTA and STAR: Environmental Responsibility and Performance}

Given the negative result of the IPO carried out analysis of the AIM Italy list, the authors want to observe if the ESG Corporate Responsibility influences in a statistically significant way the underpricing and performance of medium and large companies analyzed separately. Only large cap companies are included in ethical indices because of their ability to be transparent in ESG CR field, and these indices have averaged demonstrating good financial performance since 2008 today. If we look at the companies in the sample currently included in lists MTA and its subset STAR, we can see how the average value of underpricing of the group of companies responsible from an environmental point of view stands at $7.138 \%$, which is higher than $1.19 \%$ of non-responsible in this field. If apparently it seems that the companies responsible from an environmental point of view, considering that leads to better financial results and better environmental risks management, are rewarded by the market during the first day of trading and conclude successfully the IPO, although with a larger amount of money left on the table for issuers, inferential statistics do not allow us to reject the $\mathrm{Hp}_{0.5}$ ( $p$-value 0.3123). Certainly the results could also be affected by the small number of IPO sample included in these two lists.

$\mathrm{Hp}_{0.5}$ : The underpricing of environmentally responsible companies listed on MTA and STAR is not significantly different from that of not responsible in this area.

Despite the fact that the value of the $p$-value has been lowered considerably for these larger businesses with respect to the values of $p$-value calculated in terms of underpricing in the previous analysis, the two populations listed on STAR-MTA are not significantly different. The same can be concluded about the average values of ROE of the two populations in analysis. Although the mean (19.92 versus 13.85) and median values (11.95 versus 9.04) of these two indices are higher for sustainable businesses from an environmental point of view, the $t$-test ( $p$-value 0.5425 ) shows how the average values are not sufficiently different to reject the null hypothesis $\mathrm{Hp}_{0.6}$.

$\mathrm{Hp}_{0.6}$ : The ROE of the company of MTA and STAR lists responsible in an environmental perspective is not significantly different from that of companies non-responsible in this area.

\section{Univariate Analysis-Social Responsibility and Performance: Management of Supplier Relationships}

If the environmental responsibility projects are considered easier to be reported because they often turn out to be measurable and translatable into monetary terms, such as the case of the amount of energy saved, the above analysis did not reveal significant evidence neither for the underpricing, either as it regards the balance sheet data considered by the ROE. The analysis proceeds by comparing the population of the companies considered responsible in society with that of the companies which were not considered responsible in this analysis, focused on suppliers' assessment in terms of CSR and community. The descriptive statistic shows the average underpricing (4.881) is lower for companies engaged in this area compared to average underpricing of 
those considered not responsible (6.089); even though a consistent management of supply relationships according to the ESG Corporate Responsibility level of the company might have a positive impact on business risks management and, therefore, on company in terms of lower cost of listing, the unpaired $t$-test shows a $p$-value (0.722) that does not allow rejecting the null hypothesis $\mathrm{Hp}_{0.7}$.

$\mathrm{Hp}_{0.7}$ : The underpricing of the companies responsible in terms of suppliers' assessment is not significantly different from that of companies not responsible in this area.

Considering the same two populations with reference to observed values of ROE, the descriptive statistic shows median (11.95 versus 10.76) and average values (19.74 versus 16.35 ) slightly different for the two populations, and the unpaired $t$-test ( $p$-value 0.5765 ) confirms the non-significant difference of two populations.

\section{Univariate Analysis—Government Responsibility: Fairness and Information Transparency}

Almost half of the sampled companies have standards of fairness and information transparency on the management and business operations exceeding the obligations imposed by law and by Consob regulations for listed companies. Analyzing the observed data of companies that demonstrate a greater degree of fairness and transparency due to the non-mandatory requirements set out by the Legislative Decree no. 231/2001 and the drafting of an Ethics Code, descriptive statistics shows how mean and median in terms of underpricing (mean 6.05 of responsible versus 5.436) and ROE are very close to those observed for the population of companies that stick exclusively to the regulatory obligations imposed from admission on stock exchange (mean 15.36 of responsible versus 19.26 of no responsible). Even the unpaired $t$-test confirms the non-significant difference between the two populations in terms of underpricing ( $p$-value 0.8446) and ROE ( $p$-value 0.4839), it does not allow rejecting the null hypotheses respectively $\mathrm{Hp}_{0.8}, \mathrm{Hp}_{0.9}$.

$\mathrm{Hp}_{0.8}$ : The underpricing of the companies responsible in terms of fairness and information transparency is not significantly different from that of not responsible companies in this area.

$\mathrm{Hp}_{0.9}$ : The ROE of the companies responsible in terms of fairness and information transparency is not significantly different from that of not responsible companies in this area.

\section{Univariate Analysis-Sustainability Report}

The sustainability report is still an uncommon document among the smaller Italian companies, as it is evidenced by the dataset. Within our sample of companies that have gone public in the last seven years, only seven draw up a sustainability report (Table 4) and, of these, four are listed in the FTSE MIB index, the main index that groups the most highly capitalized companies, and one in STAR. These seven companies with their average total assets in the year before the listing of about 369 million euro, against approximately 116 million of the 77 companies in the sample that do not publish a sustainability report, prepare these disclosures in accordance with the GRI criteria, except for Assiteca that observes the guidelines of the Study Group for the Social Report, the GBS. Despite the fact that the SME sector is full of companies engaged in various areas of ESG Corporate Responsibility, and only two of them draw up a sustainability report, probably for additional costs to be incurred.

Table 4 shows the IPOs of these seven companies successfully completed, except for the debut of Poste Italian Stock Exchange, which closed just below parity. The mean and median of underpricing of the two populations, one of the companies draws up a sustainability report and one of the companies does not draw up it, are very different, as demonstrated by the frequency distribution of the displayed chart below. 
The underpricing of the companies that publish a sustainability report is of $14.56 \%$, compared to $4.9 \%$ of those who do not publish. The values of underpricing of the two groups of companies are statistically different considering a significance level of $10 \%$ ( $p$-value 0.0864 ), allowing rejecting the null hypothesis and confirming the $\mathrm{Hp}_{1.10}$.

$\mathrm{Hp}_{1.10}$ : The underpricing of the companies drawing up a sustainability report is significantly different from that of the companies not preparing it.

Table 4

The Seven Sampled Companies That Prepare a Sustainability Report

\begin{tabular}{|c|c|c|c|c|c|c|}
\hline Company & Market & Field & $\begin{array}{l}\text { Date } \\
\text { IPO }\end{array}$ & $\begin{array}{l}\text { Admission } \\
\text { price }\end{array}$ & $\begin{array}{l}\text { Return on first } \\
\text { day }\end{array}$ & ROE \\
\hline Poste Italiane & MTA-FTSE MIB & $\begin{array}{l}\text { Postal and financial } \\
\text { services }\end{array}$ & $27 / 10 / 15$ & 6.75 & $-0.74 \%$ & $3 \%$ \\
\hline Assiteca & AIM Italia-MAC & Insurance & $27 / 07 / 15$ & 1.85 & $2.05 \%$ & $26.45 \%$ \\
\hline $\begin{array}{l}\text { Aeroporto Guglielmo } \\
\text { Marconi Di Bologna }\end{array}$ & STAR & Airport & $14 / 07 / 15$ & 4.50 & $32.22 \%$ & $5.54 \%$ \\
\hline Innovatec & AIM Italia-MAC & Energy & $20 / 12 / 13$ & 3.50 & $2.69 \%$ & $-0.29 \%$ \\
\hline Moncler & MTA-FTSE MIB & $\begin{array}{l}\text { Household products } \\
\text { and fashion }\end{array}$ & $16 / 12 / 13$ & 10.20 & $46.76 \%$ & $11.95 \%$ \\
\hline Salvatore Ferragamo & MTA-FTSE MIB & Fashion & 29/06/11 & 9.00 & $10.56 \%$ & $31.49 \%$ \\
\hline $\begin{array}{l}\text { Yoox Net-A-Porter } \\
\text { Group }\end{array}$ & MTA-FTSE MIB & E-commerce & 03/12/09 & 4.30 & $8.37 \%$ & $14.62 \%$ \\
\hline
\end{tabular}

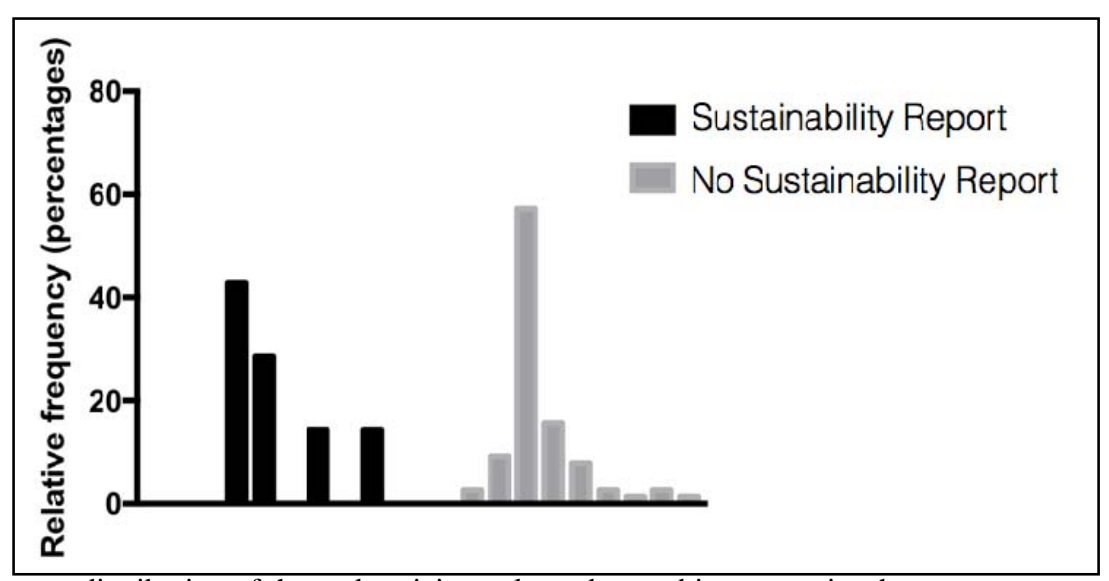

Figure 2. Frequency distribution of the underpricing values observed in companies that prepare a sustainability report and who do not prepare.

Table 5

Analysis of Underpricing Values of the Companies Drawing up a Sustainability Report

\begin{tabular}{lll}
\hline & Underpricing, sustainability report $=1$ & Underpricing, sustainability report $=0$ \\
\hline Number of values & 7 & 77 \\
Median & 8.37 & 0.26 \\
Mean & 14.56 & 4.933 \\
\hline Unpaired $t$ test & \\
\hline$P$ value & & 0.0846 \\
Significantly different $(p<0.10)$ & Yes* \\
\hline
\end{tabular}

Note. ${ }^{*} p<0.10$ 
The market, therefore, seems to reward the commitment in the Social Accounting and Reporting of these companies. Table 6 shows the statistical analysis of the two samples compared to the ROE values calculated on the balance data to 31/12 of the year before the listing. The average value, higher for the group of companies that do not publish this document, is heavily influenced by the strong presence of SMEs in this group of companies, characterized by high growth rates. Univariate analysis does not allow rejecting the null hypothesis.

$\mathrm{Hp}_{0.11}$ : The ROE of the companies drawing up a sustainability report is not significantly different from that of the companies not preparing it.

Table 6

Analysis of ROE Values of the Companies Drawing up a Sustainability Report

\begin{tabular}{lll}
\hline & ROE, sustainability report $=1$ & ROE, sustainability report $=0$ \\
\hline Number of values & 7 & 77 \\
Median & 11.95 & 10.89 \\
Mean & 13.25 & 17.73 \\
\hline Unpaired $t$ test & & \\
\hline$P$ value & & 0.6565 \\
Significantly different $(p<0.05)$ & & No \\
\hline
\end{tabular}

\section{Multivariate Analysis}

The literature defines "hot new-issue" ${ }^{9}$ the issues ${ }^{10}$ of new shares for which the demand from investors significantly exceeds the offer. During certain times and in certain areas with new issues underpricing high as investors are subject to cycles of high optimism and issuers schedule their emissions in the coincidence of these cycles. To take account of this effect, dummy year was included in the multivariate analysis as a check. Table 7 below proposed describes the average underpricing for each year for the companies in the sample: high underpricing periods are alternated with periods characterized by decreasing yields of the first day of trading and in some cases even negative.

Table 7

The Sample of IPOs for Each Year and Average Underpricing

\begin{tabular}{lll}
\hline Year & IPO & AV. underpricing \\
\hline 2015 & 24 & $5.34 \%$ \\
2014 & 25 & $3.82 \%$ \\
2013 & 16 & $3.33 \%$ \\
2012 & 4 & $20 \%$ \\
2011 & 4 & $-1.05 \%$ \\
2010 & 7 & $11.93 \%$ \\
2009 & 4 & $11.28 \%$ \\
\hline
\end{tabular}

An analysis shall firstly consider the political and economic conditions both locally and globally that inevitably affect developments in stock markets and new issues. The financial crisis of subprime mortgages, which exploded in the US, struck Europe in the period 2007-2009, collapsing stock markets, income and employment. In this crisis there are the causes of a second crisis, that of the Eurozone sovereign debt of the

\footnotetext{
${ }^{9}$ Allen, Faulhaber, Signaling by underpricing in the IPO market, Journal of Financial Economics, 1989, Vol. 23, pp. $303-323$.

${ }^{10}$ Ibboston, Jaffe, “Hot issue” markets, The Journal of Finance, 1975, Vol. 30, No. 4, pp. 1027-1042.
} 
2010-2011 period, which is immediately reflected on the financial markets, causing losses. The increasingly incisive programs implemented by the ECB to ease pressure on European banking stocks and on the interbank market brought benefits on the market from 2015, when the improved investor expectations increased the returns of the stock markets. All this has been reflected also in the number of IPOs, particularly low between 2009 and 2012. Even sectoral dynamics can influence the results of the IPO as well and the multivariate analysis includes dummy sector.

Table 8 proposes the multivariate analysis. The underpricing variable has been set as dependent variable $\mathrm{Y}$, while the control variables used in each model are: i) ROE; ii) green shoe; iii) year of foundation; iv) total assets of the previous year to IPO; v) venture backed IPOs. Starting from model 2, it has been added from time to time one of the independent variables ESG Corporate Responsibility: i) environmental responsibility; ii) responsibility in the evaluation of suppliers according to CSR; iii) responsibility to the community; iv) responsibility in the fairness and information transparency; v) preparation of the sustainability report.

Table 8

Multivariate Analysis

\begin{tabular}{|c|c|c|c|c|c|c|c|}
\hline $\mathrm{Y}=$ underpricing & Mod. 1 & Mod. 2 & Mod. 3 & Mod. 4 & Mod. 5 & Mod. 6 & Mod. 7 \\
\hline \multicolumn{8}{|l|}{ Variables ESG CR } \\
\hline Env. responsibility & & 0.938 & & & & & 0.910 \\
\hline Val. suppl. responsibility & & & 0.943 & & & & 0.929 \\
\hline Community & & & & 0.550 & & & 0.469 \\
\hline $\begin{array}{l}\text { Fairness \& } \\
\text { transparency }\end{array}$ & & & & & 0.832 & & 0.859 \\
\hline Sustainability report & & & & & & 0.295 & 0.300 \\
\hline \multicolumn{8}{|l|}{ Control variables } \\
\hline ROE & $0.044 * *$ & $0.049 * *$ & $0.047 * *$ & $0.047 * *$ & $0.049 * *$ & $0.061^{*}$ & $0.089 *$ \\
\hline Green SHOE & 0.494 & 0.495 & 0.497 & 0.452 & 0.518 & 0.624 & 0.611 \\
\hline Foundation year & 0.724 & 0.759 & 0.744 & 0.814 & 0.700 & 0.481 & 0.539 \\
\hline Tot. assets year IPO-1 & 0.732 & 0.730 & 0.731 & 0.620 & 0.784 & 0.712 & 0.618 \\
\hline VC & $0.044 * *$ & $0.046 * *$ & $0.047 * *$ & $0.050 * *$ & $0.046 * *$ & $0.064 *$ & $0.095 *$ \\
\hline N OBS & 84 & 84 & 84 & 84 & 84 & 84 & 84 \\
\hline R-SQ & 0.3345 & 0.3345 & 0.3345 & 0.3383 & 0.3349 & 0.3462 & 0.3560 \\
\hline Dummy year & Yes & Yes & Yes & Yes & Yes & Yes & Yes \\
\hline Dummy sector & Yes & Yes & Yes & Yes & Yes & Yes & Yes \\
\hline
\end{tabular}

Notes. ${ }^{*} p<0.10 ; * * p<0.05$.

The analysis shows how only the ROE and VC variables are significantly different from zero with a level that varies between $5 \%$ and $10 \%$ depending on the observed patterns. The key variables as the ESG Corporate Responsibility variables are not statistically significant. The low level of significance of the coefficients calculated in the empirical analysis is probably due to the reduced number of sample observations. In general, given the results highlighted by multivariate analysis, we can say that the market seems to not reward the IPO carried out by sustainable enterprises: these companies are in fact not subject to greater underpricing, which would highlight an award or a recognition of a higher value in the marketplace for those companies engaged in activities ESG Corporate Responsibility. 


\section{Summary and Conclusions}

The sample of companies analyzed shows that only 19 out of 84 are engaged on every area of CSR and, of these 19, only seven draw up a sustainability report. It is, therefore, evident in newly-listed Italian companies that lack a culture of social responsibility that allows structuring an ESG Corporate Responsibility strategy integrated into the business, but there are individual projects not linked. An ESG Corporate Responsibility strategy integrated in the business model assumes that the company is able to structure a process of Social Accounting, or it is able to organize tools and people that identify, measure, manage, evaluate, and communicate the ESG performance. This process is completed and formalized in the sustainability report, the document by which the company reporting to stakeholders its ESG responsibility and this disclosure is considered necessary by the financial markets to assess and reward performance in this area. Univariate statistical analysis shows that the companies which prepare a sustainability report seem to have a greater underpricing (according to univariate analysis the average underpricing for these companies is $14.56 \%$, against $4.93 \%$ of those companies not drawing up it) showing that the market recognizes and rewards the ESG Corporate Responsibility. In terms of univariate analysis, the group of companies which prepare a sustainability report appear to have a significantly different underpricing (10\% confidence level) from the group of newly listed that do not prepare the sustainability report. There are, therefore, those involved in the listing process to enhance the ESG Corporate Responsibility strategies issuing the IPO shares for a higher offer price, but it is the market that in the first day of trading seems to recognize and reward responsible companies from the environmental, social and governance point of view. Considering that the equity value is given by the number of shares multiplied by the market price of a single share, the most underpricing leads to a greater equity value. The results presented by univariate analysis are not, however, confirmed by multivariate analysis, which returns coefficients not significantly different from zero for the variables of interest. The insignificance of the data can be attributed to the small number of companies in dataset that prepare a Sustainability Report, seven precisely, and the criticality of the period analyzed affected by the two financial crises. In addition, companies have already gained the capability of reporting their extra-financial performance which is in average larger and, therefore, able to bear all those costs-monetary and otherwise - that the Social Accounting and Reporting involves. Overall, however, the sample is composed for $76 \%$ that are SMEs. After these observations, it is possible to draw a description of the ESG Corporate Responsibility under Italian Market. In young newly-listed Italian companies is not strong and widespread the integration of CSR into strategy, decision making, and reporting system. The companies able to integrate CSR into strategy and decision processes, however, are concentrated in the lists with the largest capitalization, FTSE MIB and STAR, and this managerial ability allows them to draw up a sustainability report. Since 2017 it will be mandatory for large organizations drafting a Sustainability Report. Although every company can choose different reporting standards with their own methodology, it is evident that it is widely recognized the importance of extra-financial information in the companies' valuations. The extra-financial factors, in fact, create value only if identified by an accounting process because only what is measured is managed.

\section{References}

Allen, F., \& Faulhaber, G. R. (1989). Signalling by underpricing in the IPO market. Journal of Financial Economics, $23,303-323$. Baron, D. P., \& Holmström, B. (1980). The investment banking contract for new issues under asymmetric information: Delegation and the incentive problem. The Journal of Finance, 35(5), 1115-1138. 
Beatty, R. P., \& Ritter, J. R. (1986). Investment banking, reputation and the underpricing of initial public offering. Journal of Financial Economics, 15, 213-232.

Benveniste, L. M., \& Spindt, P. A. (1989). How investment bankers determine the offer price and allocation of new issues. Journal of Financial Economics, 24, 343-361.

Brennan, M. J., \& Franks, J. (1997). Underpricing, ownership and control in initial public offerings of equity securities in the UK. Journal of Financial Economics, 45(3), 391-413.

Cavaco, S., \& Crifo, P. (2014). CSR and financial performance: Complementary between environmental, social and business behaviours. Applied Economics, 46(27), 3323-3338.

Dell’Acqua, A., Etro, L., Leonardo, A., Murri, M., \& Tetia, E. (2014). IPO underpricing and aftermarket performance in Italy. SDA Bocconi School of Management, Bocconi University.

Eugene, F., \& French, K. (1992). The cross-section of expected stock returns. The Journal of Finance, 47(2), 427-465.

Ewing, E. (2014). The CFO and sustainability reporting chain: Why CFOs should care about sustainability reporting. Workiva.

Friedman, M. (1970). The social responsibility of business is to increase its profits. The New York Times Magazine.

Gangi, F. (2013). La finanza etica durante la crisi finanziaria del nuovo millennio. Modelli teorici ed evidenze empiriche, p. 76.

Hassel, L. G., \& Semenova, N. (2013). The added value of esg/sri on company and portfolio levels-What can we learn from research? SIRP working paper $13-2$.

Hillier, D., Jaffe, J., Jordan, B., Westerfield, R., \& Ross, S. (2013). Decisioni finanziarie e rischio d’impresa, custom publishing per l’Università Cà Foscari, da Finanza Aziendale. McGrow-Hill, cap. 10, p. 285 e ss.

Hososa, M., \& SuzukiI, K. (2015). Using management control system to implement Csr activities: An empirical analysis of 12 Japanese companies. Business Strategy and the Environment, 24(7), 628-642.

Huefner, R. J., \& Tschopp, D. (2014). Comparing the evolution of CSR reporting to that of financial reporting. Springer Science and Business Media Dordrecht.

Ibboston, R. G., \& Jaffe, J. J. (1975). “Hot issue” markets. The Journal of Finance, 30(4), 1027-1042.

Lev, B. (2003). Intangibles. Gestione, valutazione e reporting delle risorse intangibili delle aziende (p. 3). Etas.

Li, O. Z., \& Zhuang, Z. (2012). Management guidance and the underpricing of seasoned Equity offering. Contemporary Accounting Research, 29(3), 710-737.

Lucy, U., \& Onyekkwelu. (2014). Corporate social accounting and the enhancement of information disclosure among firms in Nigeria: A case of some selected firms in Nigeria. Journal of Economics and Sustainable Development, 5(6), 35-44.

Moon, J., \& Vogel, D. (2008). Corporate social responsibility, government, and civil society. Oxford, cap. 13, p. 303.

Moore, C. (2014). Corporate social responsibility and creating shared value: What's the difference? Heifer International, p. 2.

Osterwalder, A., \& Pigneur, Y. (2012). Creare modelli di business. FAG.

Perrini, F., \& Tencati, A. (2008). Corporate social responsibility: Un nuovo approccio strategico alla gestione d'impresa. Egea.

Rahman, S. (2011). Evaluation of definitions: Ten dimensions of corporate social responsibility. World Review of Business Research, 1(1), 166-176.

Ritter, J. R., \& Welch, I. (2002). A review of IPO activity, pricing and allocations. Journal of Financial Economics, 57(4), 1795-1828。

Rock, K. (1986). Why new issues are underpriced. Journal of Financial Economics, 15, 187-212.

Rubino, M., \& Vitolla, F. (2012). Il reporting socio-ambientale e di sostenibilità. Contenuti della disclosure e qualità delle informazioni (p. 15). Egea.

Ruud, J. S. (1993). Underwriter price support and the IPO underpricing puzzle. Journal of Financial Economics, 34(2), 135-151. Rydqvist, K. (1997). IPO underpricing as tax-efficient compensation. Journal of Banking and Finance, 21(3), 295-313.

Silva, F. (in G. Garioni). (2008). Responsabilità sociale e finanziaria, un’alleanza sempre più conveniente. Analisi e commenti.

www.aimnews.it

www.borsaitaliana.it 